\title{
Secondary xylary features in proving truth/falsity of an alibi: Examples of three important Indian commercial woods
}

\author{
Sandip More ${ }^{1,2}$, Dipak Kumar Paruya1, Subir Bera ${ }^{1 *}$ \\ ${ }^{1}$ Department of Botany, Centre of Advanced Study, University of Calcutta, Kolkata, West Bengal, India, ${ }^{2}$ Geological Studies Unit, \\ Indian Statistical Institute, Kolkata, West Bengal, India
}

Received: 15.04.2017

Accepted: 31.05.2017

Published: 03.06.2017

*Address for correspondence:

Subir Bera, Department of

Botany, Centre of Advanced

Study, University of Calcutta,

35, Ballygunge Circular

Road, Kolkata - 700 019,

West Bengal, India.

Phone: +91-033-

2461 4959/5445.

E-mail: berasubir@yahoo.

co.in

\begin{abstract}
Secondary xylary characters of wood are useful to identify a wood up to its generic or specific level and thus may prove or disprove the alibi of the retailers, i.e., a wood is genuine or not. In this study, 26 wood samples were collected from the local markets of Baruipur, Sealdah and Garia in Kolkata, West Bengal. Among them, 8 were sold as 'Sandal wood' (Santalum album), 4 as "Red Sanders" (Pterocarpus santalinus), and 14 as "Sal wood" (Shorea robusta). Results indicate that xylotomical features of most of the collected "sandal wood" and "red sander" samples did not match with the reference $S$. album and $P$. santalinus samples whereas most of the collected "Sal wood" samples from furniture shops matched with the reference samples of $S$. robusta. This study successfully indicates that xylotomical investigations of commercial wood may establish the authenticity of wood of commerce.
\end{abstract}

KEY WORDS: Adulteration, commercial wood, forensic xylotomy, India, provenance of alibi, secondary xylary characters

\section{INTRODUCTION}

Xylotomical features of wood may prove or challenge an alibi of wood traders and help identify the authenticity of the wood. Wood related evidences are rarely used in a criminal investigation and are often overlooked due to lack of awareness of its value, or lack of knowledge of how to properly collect and/or evaluate that evidence.

The main components of wood, i.e., tracheids, vessels, vascular rays, fibers, and axial parenchyma help to identify a wood up to its family and genus/species level. The identification and comparison of wood evidence have been proved useful in the investigation of earlier criminal cases (Graham, 1997; Schweingruber, 1988). Evidence from wood has proven an important resource in criminal and civil courts since 70's (Kerley and Ubelaker, 1978; Vanezis et al., 1978; Willey and Heilman, 1987; Schweingruber, 1988; Miller, 1994; Quatrehomme et al., 1997). Wood analysis played a crucial role in solving one earlier famous case, the kidnapping and murder of the infant son of aviator Charles Lindbergh from his New Jersey home in 1932 (Graham, 1997).
It is a common practice for wood traders to sell lowquality cheap woods with an alibi of genuine high-quality expensive ones. Thus, the analysis of microscopic xylotomical features of commercially important pricey woods and their counterfeits can be helpful to check the quality of the products. Keeping in view the usefulness of xylotomical study in forensic investigations this study was undertaken to check the authenticity of three economically important woody plants, i.e., Sandal wood (Santalum album), red sanders (Pterocarpus santalinus), and Sal wood (Shorea robusta). Sandal wood (S. album) is a tree with a highly aromatic wood. It is economically and culturally important to many countries around the Pacific and Eastern Indian Ocean regions where it grows or is traded. It has been in use for at least 4,000 years and is prized for making furniture, ornaments, sacred objects, carvings, and joss sticks (incense). In India, these plants grow almost exclusively in the forests of Karnataka, followed by Tamil Nadu, Kerala, and Andhra Pradesh. P. santalinus (red sanders) is another economically important woody plant used for coloring, dyeing and also in religious purposes. Economical significance of S. robusta (local name "Sal") as a timber plant has been well established. 


\section{MATERIALS AND METHODS}

About 12 samples were collected from markets of Baruipur $\left(22^{\circ} 22^{\prime} \mathrm{N}, 88^{\circ} 26^{\prime} \mathrm{E}\right)$, Sealdah $\left(22^{\circ} 34^{\prime} \mathrm{N}, 88^{\circ} 22^{\prime} \mathrm{E}\right)$, and Garia $\left(22^{\circ} 27^{\prime}\right.$ N, $88^{\circ} 23^{\prime}$ E) in Kolkata sold as 'Sandal wood" and "Red sanders" and 14 samples were collected from different furniture shops at Garia and Baruipur in Kolkata sold as "Sal" wood. Details of sample numbers, collection sites and alibi of traders of the collected wood samples are presented in Table 1.

For xylotomical study solid, compact and uninfected wood samples were collected. The external features of the wood samples were described on the basis of color, texture, hardness, and presence/absence of growth rings. Identification of woods requires detailed observation of their internal features. This can be achieved through microscopic observations of fine sections of the wood samples. All the woods were sectioned along transverse (T.S.), tangential longitudinal (T.L.S) and radial longitudinal (R.L.S) planes with the help of fine razor, and permanent slides were prepared. For obtaining fine section of wood, samples were boiled 10-15 min and then kept in FAA (70\% ethyl alcohol $90 \mathrm{cc}$, glacial acetic acid $5 \mathrm{cc}$, and formalin $5 \mathrm{cc}$ ) medium for 1-2 days for softening of the wood samples (Clavers, 1911). Fine wood sections were dehydrated with the help of different concentrations of ethyl alcohol solutions (30\%, 50\%, 70\%, 90\%, and absolute alcohol) and Safranin solution (2\%). Finally, dehydrated wood sections were mounted in euperol and labeled accordingly. For the identification of prepared wood slides, the published records (Metcalfe and Chalk, 1950; Illic, 1987), photographs, index permanent slides kept at Herbarium cum Museum, Department of Botany, University of Calcutta were consulted.

Correspondence and Cluster analyses were performed with the measurement data such as mean vessel diameter, vessel wall thickness, the frequency of vessels per sq $\mathrm{mm}$, ray dimension (width and height), ray histology, and fiber characters (wall thickness, septation, etc.) of collected wood samples. Both analyses were employed to reduce the number of variables in the collection to a smaller set, revealing internal structure, group type variables, and detect covariance. For the Cluster analysis, Ward's method (Ward, 1963) was used, and the Euclidean distance with the variables rescaled to $0-1$. Field photos were taken using a digital camera (Canon SX 120 IS), and photographs of thin sections of secondary wood structures were taken using a light compound microscope (Carl Zeiss Axioskop 2).
Table 1: Details of collected wood samples

\begin{tabular}{lll}
\hline Sample number & Location of sample collection & Alibi \\
\hline SW-1 & Baruipur & Sandal wood \\
SW-2 & Baruipur & Sandal wood \\
SW-3 & Baruipur & Sandal wood \\
SW-4 & Sealdah & Sandal wood \\
SW-5 & Baruipur & Sandal wood \\
SW-6 & Sealdah & Sandal wood \\
SW-7 & Garia & Sandal wood \\
SW-8 & Baruipur & Sandal wood \\
RSW-9 & Garia & Red Sanders \\
RSW-10 & Sealdah & Red Sanders \\
RSW-11 & Garia & Red Sanders \\
RSW-12 & Baruipur & Red Sanders \\
SRW-1 & Garia & Sal \\
SRW-2 & Baruipur & Sal \\
SRW-3 & Baruipur & Sal \\
SRW-4 & Garia & Sal \\
SRW-5 & Garia & Sal \\
SRW-6 & Baruipur & Sal \\
SRW-7 & Baruipur & Sal \\
SRW-8 & Garia & Sal \\
SRW-9 & Garia & Sal \\
SRW-10 & Garia & Sal \\
SRW-11 & Baruipur & Sal \\
SRW-12 & Baruipur & Sal \\
SRW-13 & Garia & Sal \\
SRW-14 & Baruipur & Sal \\
\hline & &
\end{tabular}

\section{RESULTS AND DISCUSSION}

Among 12 collected wood samples (SW1-SW12) from Baruipur, Garia and Sealdah in Kolkata, 8 were sold as "Sandal wood" (Figure 1), and 4 were sold as "Red sanders" (Figure 2). Among 8 "sandal wood" samples (SW 1-8) only 2 samples (SW-2 and SW-7) proved to be real S. album but rest 6 samples (SW-1, SW-3, SW-4, SW-5, SW-6, and SW-8) did not resemble with the $S$. album reference samples. In the 6 "fake" sandal wood samples it was found that 4 were closely identical with Aegle marmelos (SW-1, SW-4, SW5, and SW-8; Figure 1) and 2 resembled with species of Santalum other than S. album (SW-3 and SW-6; Figure 1). Santalum has 16 different species among which S. album and $S$. spicatum are used for aromatic and holy purposes. S. spicatum is commonly inhabitant of Australia and not growing in India. The secondary wood characters of SW-3 and SW-6 were similar with the genus Santalum, but not exactly with S. album.

For 4 "red sander" samples (RSW 9-12), it was evident that only one sample (RSW-10) was original P. santalinus (red sanders) but rest 3 (RSW-9, RSW-11, and RSW-12) were closely resembling with secondary wood characters observed in Ceriops decandra (Figure 2). C. decandra is commonly inhabitant of halophytic mangrove vegetation and found in the Indian Sundarbans regions. The Sundarbans is around $100 \mathrm{~km}$ away from the city of Kolkata. Ceriops decandra wood is morphologically closely identical with red sanders and is commonly adulterated as a red sander in the markets of Kolkata.

Current Botany • Vol 8 • 2017 


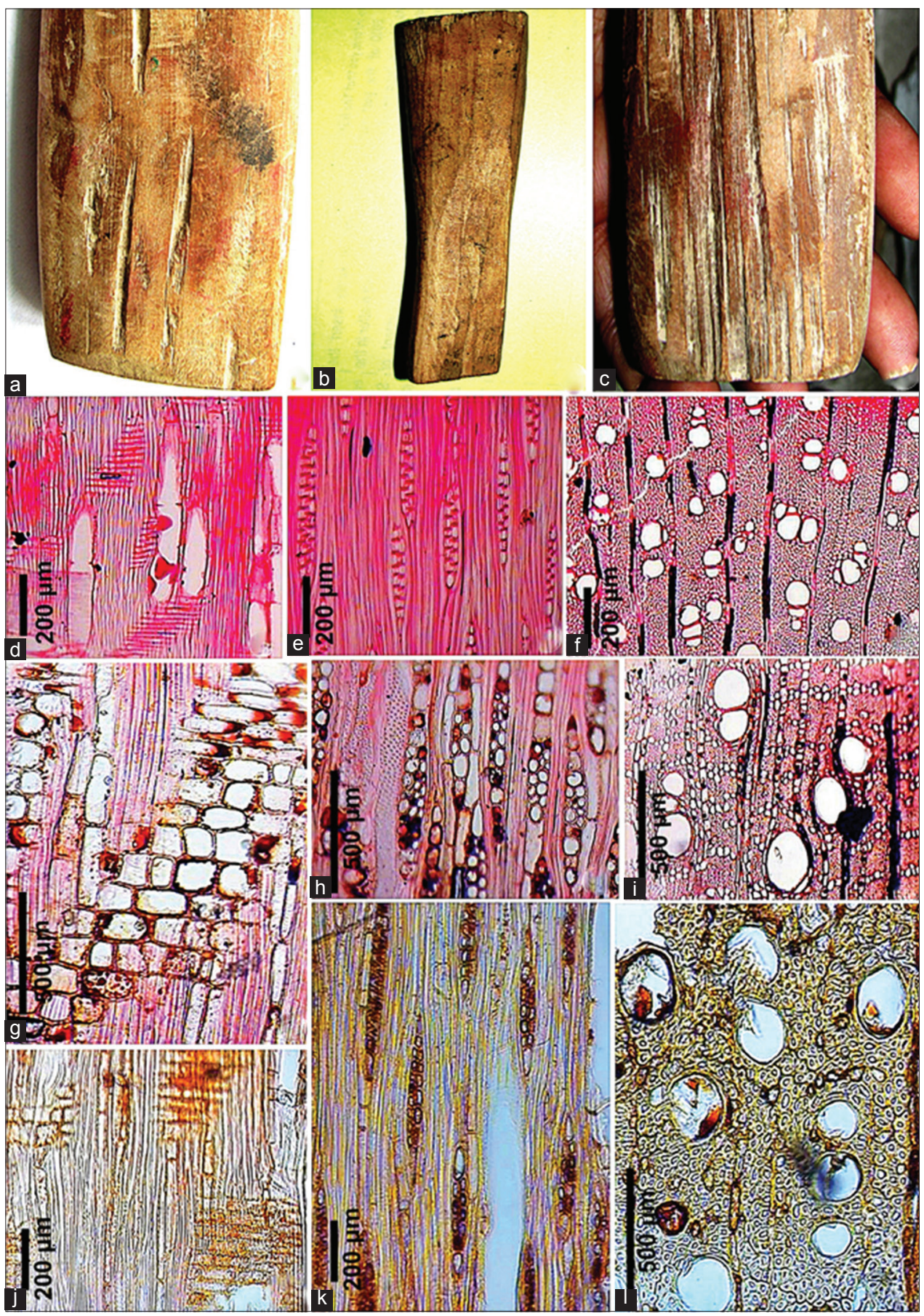

Figure 1: (a-c) Collected "sandal wood" samples, (d-f) radial longitudinal section (RLS), tangential longitudinal section (TLS), and transverse section (TS) of wood resembling Aegle marmelos, (g-i) RLS, TLS and TS of wood resembling Santalum spp., (j-l) RLS, TLS, and TS of wood resembling real Santalum album

Among 14 "Sal wood" samples, 12 (SRW 1-8, 10-12, 14) were found as authentic S. robusta wood. Amazingly, it was found that 2 (SRW-9 and SRW-13) sold as 'Sal wood' (S. robusta) were not similar in their anatomical features with reference wood samples of S. robusta. These two (SRW-9 and SRW-13) samples showed similarities with species of Dalbergia in their anatomical characters but not exactly with Dalbergia sissoo and thus considered here as Dalbergia sp. Type-I and Dalbergia sp. Type-II (Figure 3).

\section{Salient xylotomical features of wood samples sold as "Sandal wood"}

\section{Samples Nos. SW-2 and SW-7}

Wood diffuse porous; vessels medium to large, mostly solitary and in radial multiples of 2-3, evenly distributed 3-5 cells per sq $\mathrm{mm}$, round to oval in cross section, thick walled 13-15 $\mu \mathrm{m}$ in thickness and 80-110 $\mu \mathrm{m}$ in diameter, long with truncate ends; perforation plate 


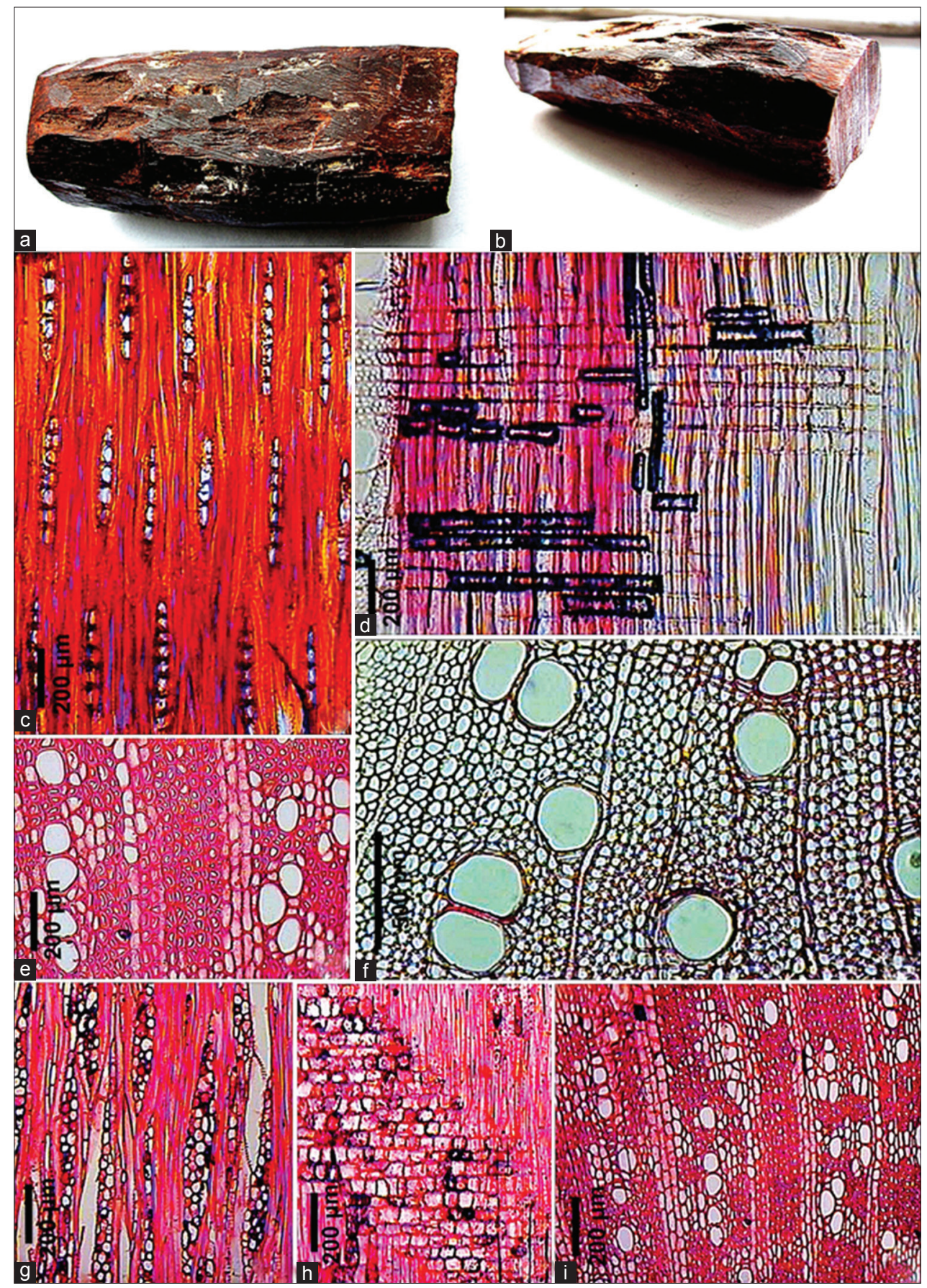

Figure 2: ( $a$ and b) Collected "red sanders" samples, (c, d and f) radial longitudinal section (RLS), tangential longitudinal section (TLS), and transverse section (TS) of wood resembling real Pterocarpus santalinus, (g, h, e and i) TLS, RLS, and TS of wood resembling Ceriops decandra

simple, intervessel pitting alternate; axial parenchyma paratracheal and apotracheal, parenchyma cells round to oval in cross section, $19 \mu \mathrm{m}$ in diameter; xylem rays 1-2 seriate, 6-8 cells high; ray tissue heterocellular, made up of procumbent and upright cells; fibers in radial rows, thick walled, septate, circular in cross section, 16-18 $\mu \mathrm{m}$ in diameter. All the abovementioned xylotomical features are closely similar with S. album L. (Santalaceae). Hence, the sold samples
(SW-2, SW-7) are identified as 'authentic' Sandal wood samples.

\section{Sample Nos. SW-3 and SW-6}

Wood diffuse porous; vessel diameter moderate, $130-140 \mu \mathrm{m}$ in diameter, mostly solitary and in radial multiples of 2-3, wall 15-17 $\mu \mathrm{m}$ in thickness and 4-7 cells in per sq $\mathrm{mm}$, vessels long, perforation plate simple, intervessel pitting alternate; axial parenchyma both 

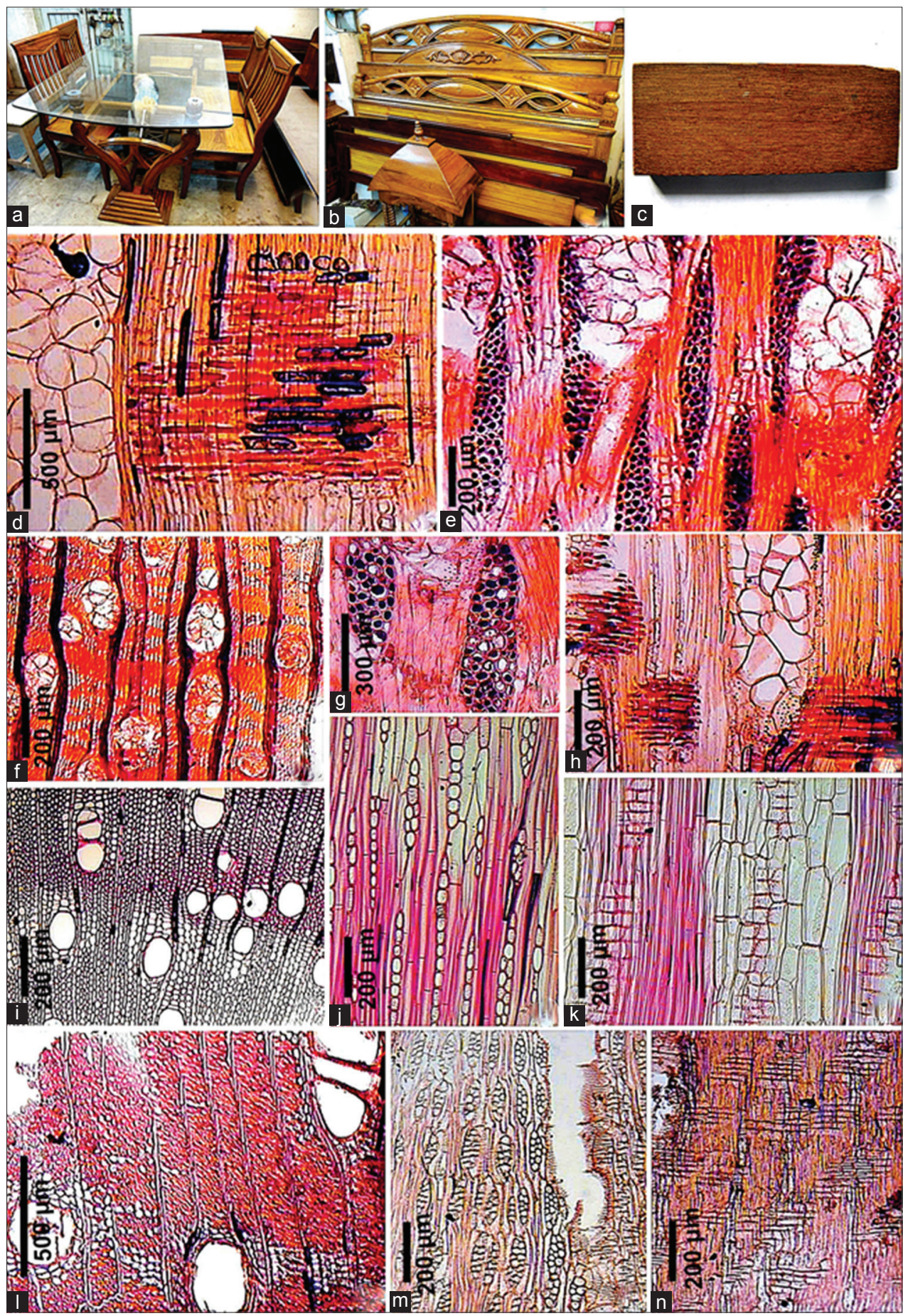

Figure 3: (a-c) Collected "Sal wood" samples from furniture shops, (d and h, e and g, f) radial longitudinal section (RLS), tangential longitudinal section (TLS), and transverse section (TS) of wood resembling real Shorea robusta, (i-k) TS, TLS, and RLS of wood resembling Dalbergia sp. Type-I, (I-n) TS, TLS and RLS of wood resembling Dalbergia sp. Type-II.

paratracheal and apotracheal, thick walled oval in cross section, $17.5 \mu \mathrm{m}$ in diameter; ray cells mostly 2-3 seriate, in some cases uniseriate, multiseriate rays with long uniseriate wings, 8-10 cells high; fibers aligned in radial rows, thick walled, septate, oval in cross section, 11-13 $\mu \mathrm{m}$ in diameter; ray tissue heterocellular, made up of procumbent and upright cells, some cells are square. On the basis of vessel diameter, vessel wall thickness, vessel frequency, diameter of parenchyma, ray tissue width and ray tissue height, it seems that the wood samples were related with the genus Santalum of the family Santalaceae but not exactly with $S$. album. Many of the species of the genus Santalum do not have any commercial value, and present wood may represent any of these non-commercial 
species of Santalum. The other commercial species S. spicatum has not been considered as it does not grow in India. Hence, the supplied samples (SW-3, SW-6) were identified as 'fake' Sandal wood samples.

\section{Sample Nos. SW-1, SW-4, SW-5, and SW-8}

Wood diffuse porous; vessel diameter moderate, 100$120 \mu \mathrm{m}$ in diameter, mostly multiple of 2-3 and in some cases solitary, round to oval in cross section, thin walled 12-14 $\mu \mathrm{m}$ in thickness, long, perforation plate simple, intervessel pitting opposite; axial parenchyma abundant and apotracheal (paratracheal condition scanty), forms single layer concentric ring, thick walled, mostly oval in cross section, 16-17 $\mu \mathrm{m}$ in diameter; ray cells 3-4 seriate, 8-11 cells high; fibers aligned in radial rows, thick walled nonseptate, 7-10 $\mu \mathrm{m}$ in diameter; ray tissue mostly homocellular mostly made up of procumbent cells, rarely with upright cells.

All the above mentioned microscopic characters were more similar to A. marmelos (L) Corr. Serr. (Rutaceae) rather than S. album L. In S. album, intervessel pitting is an alternate, axial parenchyma is apotracheal and paratracheal, ray tissue heterogeneous, ray cell type procumbent and upright, fibers thick walled and septate. Hence, the samples (SW-1, SW-4, SW-5, and SW-8) were identified as 'fake' sandal wood. Comparative account of salient xylotomical characters of S. album, Santalum sp., and $A$. marmelos are presented in Table 2.

\section{Salient xylotomical features of wood samples sold as "red sanders"}

\section{Sample No. RSW-10}

Wood diffuse porous; vessels diameter moderate, 90$100 \mu \mathrm{m}$ in diameter, solitary, multiples of $2-3$, round to oval in cross section, thick walled 13-15 $\mu \mathrm{m}$ in thickness, long, perforation plate simple, intervessel pitting alternate; ray cells uniseriate (biserite condition very rare), 4-10 cells high; ray tissue heterocellular, mostly procumbent, some are upright; fibers radial in alignment, nonseptate, thick walled, 16-18 $\mu \mathrm{m}$ in diameter. Xylotomical features are closely comparable with P. santalinus L.f. of the family Fabaceae. Hence, the sold sample (RSW-10) is proved to be authentic red sanders wood.

\section{Sample Nos. RSW-9, RSW-11, and RSW-12}

Wood diffuse porous; vessels mostly solitary, 80-90 $\mu \mathrm{m}$ in diameter, long, perforation plate simple, intervessel pitting opposite; axial parenchyma apotracheal with crystals, round to oval in cross section, 23-27 $\mu \mathrm{m}$ in diameter; ray cells 2-4 seriate, 16-20 cells height; fibers radial in alignment, nonseptate, thick walled, 18-20 $\mu \mathrm{m}$ in diameter; ray tissue heterocellular, mostly procumbent and sometimes upright. On the basis of intervessel pitting, axial parenchyma, diameter of parenchyma and ray cell type, and ray tissue width and height, the characters are analogs to xylotomical features of Ceriops decandra (Griffith) Ding Hou. of the family Rhizophoraceae and hence the samples (RSW-9, RSW-11, and RSW-12) are proved to be fake red sanders wood. Comparative account of detailed xylotomical characters of P. santalinus and Ceriops decandra are presented in Table 3.

\section{Salient xylotomical features of wood samples sold as "Sal wood"}

Samples Nos. SRW 1, SRW 2, SRW 3, SRW 4, SRW 5, SRW 6, SRW 7, SRW 8, SRW 10, SRW 12, and SRW 14

Wood diffuse porous; vessel mostly solitary and in some cases radial multiple of 2, medium sized, oval in cross section, thick walled, 12-14 $\mu \mathrm{m}$ in thickness, 180$205 \mu \mathrm{m}$ in diameter, 6-8 cells per sq $\mathrm{mm}$, long with truncate or tailed ends, perforation simple, intervessel pits alternate, sometimes blocked with gummy substances and tylosoids, axial parenchyma paratracheal as well as

Table 2: Numerical data of secondary wood characters of Santalum album, Santalum sp., and Aegle marmelos

\begin{tabular}{|c|c|c|c|}
\hline Wood characters & Santalum album & Santalum spp. & Aegle marmelos \\
\hline Diffuse porous & Present & Present & Present \\
\hline Growth ring & Absent & Absent & Absent \\
\hline Vessel diameter in $\mu \mathrm{m}$ & $80-110$ & $130-140$ & $100-120$ \\
\hline Vessel wall thickness $\mu \mathrm{m}$ & 13 & 17.5 & 14 \\
\hline Vessel frequency/sq mm & $3-5$ & $4-7$ & $4-6$ \\
\hline Inter-vessel pitting & Alternate & Alternate & Opposite \\
\hline Axial parenchyma & Apotracheal and paratracheal & Apotracheal and paratracheal & Apotracheal \\
\hline Diameter of parenchyma in $\mu \mathrm{m}$ & $13-15$ & $15-17$ & $16-17$ \\
\hline Ray tissue & Heterogeneous & Heterogeneous & Homogenous \\
\hline Ray cell types & Procumbent and upright & Procumbent and upright & Procumbent \\
\hline Ray tissue width & $1-2$ & $2-3$ & $3-4$ \\
\hline Ray tissue height & $6-8$ & $12-18$ & $8-11$ \\
\hline Fiber & $\begin{array}{l}\text { Thick walled, septate, } 16-17 \mu \mathrm{m} \text { in } \\
\text { diameter }\end{array}$ & $\begin{array}{l}\text { Thick walled, septate, } 11-13 \mu \mathrm{m} \text { in } \\
\text { diameter }\end{array}$ & Nonseptate, 6-7 $\mu \mathrm{m}$ in diameter \\
\hline
\end{tabular}


apotracheal, apotracheal diffuse, scattered and in some places aggregated, paratracheal parenchyma scanty, parenchyma cells thin walled, 13-17 $\mu \mathrm{m}$ in diameter; xylem rays 4-5 seriate, 25-28 cells high; rays heterocellular composed of procumbent and upright cells; fibers thick walled, nonseptate and 17-19 $\mu \mathrm{m}$ in diameter; gum canals longitudinal, mostly solitary, 70-78 $\mu \mathrm{m}$ in diameter. The above-mentioned characters are similar with real S. robusta Roth. of the family Dipterocarpaceae. Thus, the supplied samples (SRW 1, SRW 2, SRW 3, SRW 4, SRW 5, SRW 6, SRW 7, SRW 8, SRW 10, SRW 12, and SRW 14) are identified as 'authentic' Sal wood.

\section{Sample No. SRW-9}

Wood diffuse porous; vessels mostly solitary, 180-190 $\mu \mathrm{m}$ in diameter, 5-9 cells per sq mm, long with truncate ends, perforation simple, intervessel pits opposite, large, oval in cross-section, wall 5-8 $\mu \mathrm{m}$ in thickness; axial parenchyma apotracheal and paratracheal, paratracheal parenchyma form sheath; parenchyma oval in cross section, 30-35 $\mu \mathrm{m}$ in diameter; xylem rays fine, uniseriate and 6-13 cells high; rays heterocellular composed of procumbent and upright cells; fibers thick walled, non-septate, 19-21 $\mu \mathrm{m}$ in diameter. All the wood characters closely resemble with the genus Dalbergia of the family Fabaceae but not exactly with D. sissoo. Thus, the wood is identified as Dalbergia sp. Type I and proved to be "fake" Sal wood.

\section{Sample No. SRW-13}

Wood diffuse porous; vessels diameter large, 310-340 $\mu \mathrm{m}$ in diameter, mostly solitary and in radial multiple of 2-3, thick walled, $17.5 \mu \mathrm{m}$ in thickness, $14-19$ cells per sq $\mathrm{mm}$, long with truncate ends, perforation simple, intervessel pits opposite; axial parenchyma apotracheal and paratracheal; parenchyma oval in cross section, 31-32 $\mu \mathrm{m}$ in diameter; xylem rays biseriate and 4-5 cells high; rays homocellular, composed of procumbent cells; fibers thick walled, nonseptate, 16-18 $\mu \mathrm{m}$ in diameter. Again the secondary xylary characters closely resemble with the genus Dalbergia of the family Fabaceae but not exactly with $D$. sissoo and Dalbergia sp. Type-I. Thus, the wood is identified as Dalbergia sp. Type II and proved to be "fake" Sal wood sample. Comparative account of detailed xylotomical characters of S. robusta, Dalbergia sp. Type-I and Dalbergia sp. Type-II are presented in Table 4.

Correspondence analysis (CA) was applied to the numerical data (Table 2) of 8 sandal wood (S. album) samples using the statistical program Statistica 6 (Figure 4). In the biplot with a variance of $91.51 \%$ and $8.487 \%$ in axis 1 and 2, respectively, S. album, Santalum sp. and A. marmelos occupied three different positions in the correspondence biplot
Table 3: Numerical data of secondary wood characters of Pterocarpus santalinus and Ceriops decandra

\begin{tabular}{lll}
\hline Wood characters & Pterocarpus santalinus & Ceriops decandra \\
\hline Diffuse-porous & Present & Present \\
Growth ring & Absent & Absent \\
Vessel diameter in $\mu \mathrm{m}$ & $110-120$ & $90-100$ \\
Vessel wall thickness $\mu \mathrm{m}$ & $13-15$ & $8-10$ \\
Vessel frequency/sq mm & $4-6$ & $7-9$ \\
Inter-vessel pitting & Alternate & Opposite \\
Axial parenchyma & Apotracheal & Apotracheal, \\
& & crystaloferous \\
Diameter of parenchyma & $25-27$ & $39-43$ \\
in $\mu \mathrm{m}$ & & \\
Ray tissue & Heterocellular & Heterocellular \\
Ray cell types & Procumbent and & Procumbent and \\
& upright & square \\
Ray tissue width in cells & 1 & $2-3$ \\
Ray tissue height in cells & $8-10$ & $16-18$ \\
Fiber & Nonseptate, 16-18 $\mu$ m & Nonseptate, 16-18 $\mu \mathrm{m}$ \\
& in diameter & in diameter \\
Gum canal & Absent & Absent \\
\hline
\end{tabular}

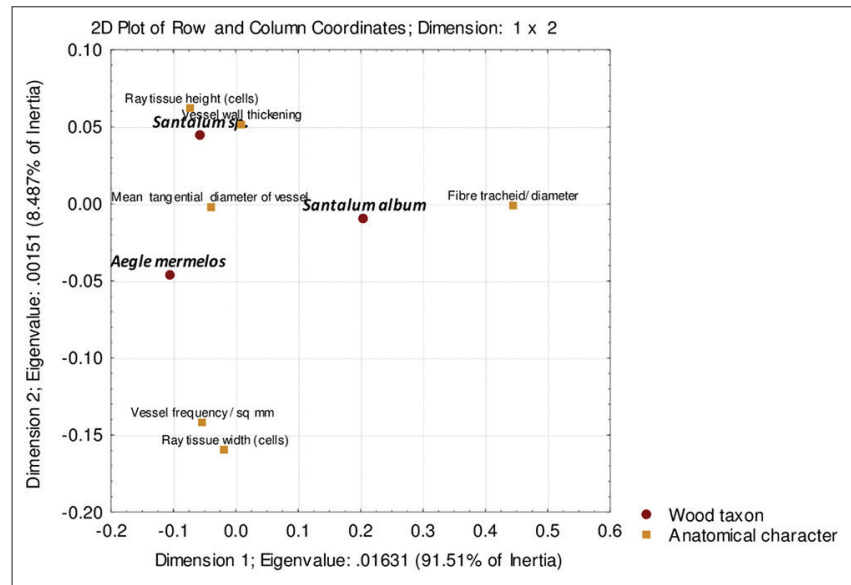

Figure 4: Biplot showing the results of correspondence analysis of collected Sandal woods and their xylotomical characters

due to the difference in the secondary xylem characters of the three different types of plant taxa (Figure 4). Tree diagram of hierarchical cluster analysis of Santalum wood samples was also performed using the Ward's method. The Euclidean distance in the hierarchical cluster shows the significant difference between S. album, Santalum sp. and A. marmelos wood samples by their numerical characters (Figure 5). It was not possible to perform correspondence analysis and hierarchical cluster analysis for the numerical data (Table 3) of P. santalinus (Red Sanders) as for their analysis at least three taxa are needed.

Correspondence analysis was also applied to the numerical data (Table 4) of $14 \mathrm{Sal}$ (S. robusta) wood samples using the statistical program Statistica 6 (Figure 6). In the biplot with a variance of $89.65 \%$ and $10.35 \%$ in axis 1 and 2 , respectively, S. robusta, Dalbergia sp. Type- I and Dalbergia sp. Type-II took again three different positions in the 
Table 4: Numerical data of secondary wood characters of Shorea robusta, Dalbergia Sp. Type-I and Dalbergia sp. Type-II

\begin{tabular}{llll}
\hline Wood characters & Shorea robusta & Dalbergia sp. Type-I & Dalbergia sp. Type-II \\
\hline Diffuse porous & Present & Present & Present \\
Growth ring & Absent & Absent & Absent \\
Vessel diameter in $\mu \mathrm{m}$ & $180-200$ & $180-190$ & $320-340$ \\
Vessel wall thickness in $\mu \mathrm{m}$ & $12-14$ & $5-8$ & $14-18$ \\
Vessel frequency/sq $\mathrm{mm}$ & $6-8$ & $5-9$ & $14-19$ \\
Inter-vessel pitting & Alternate & Opposite & Opposite \\
Axial parenchyma & Paratracheal and apotracheal & Paratracheal and apotracheal & Paratracheal and apotracheal \\
Diameter of parenchyma & $27-30$ & $33-35$ & $31-32$ \\
Ray tissue & Heterocellular & Heterocellular & Homocellular \\
Ray cell types & Procumbent and upright & Procumbent and upright & Procumbent \\
Ray tissue width & $4-6$ & 1 & 2 \\
Ray tissue height & $24-29$ & $8-10$ & $6-6$ \\
Fiber & Thick walled nonseptate, 18-20 $\mu \mathrm{m}$ in & Thick walled nonseptate, 19-21 $\mu \mathrm{m}$ in & Thick walled nonseptate, 16-18 $\mu \mathrm{m}$ in \\
& diameter & diameter & diameter \\
Gum canal & Present, 78-83 $\mu \mathrm{m}$ in diameter & Absent & Absent
\end{tabular}

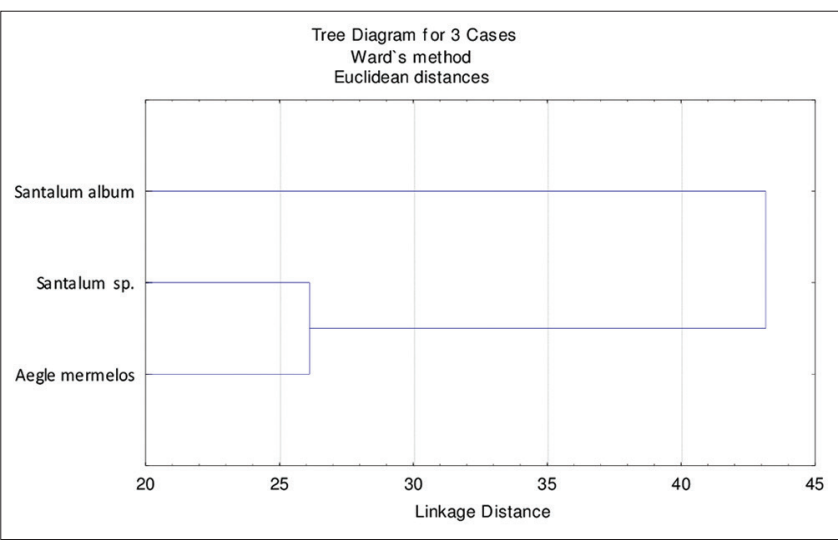

Figure 5: Tree diagram of hierarchical cluster analysis of Sandal woods

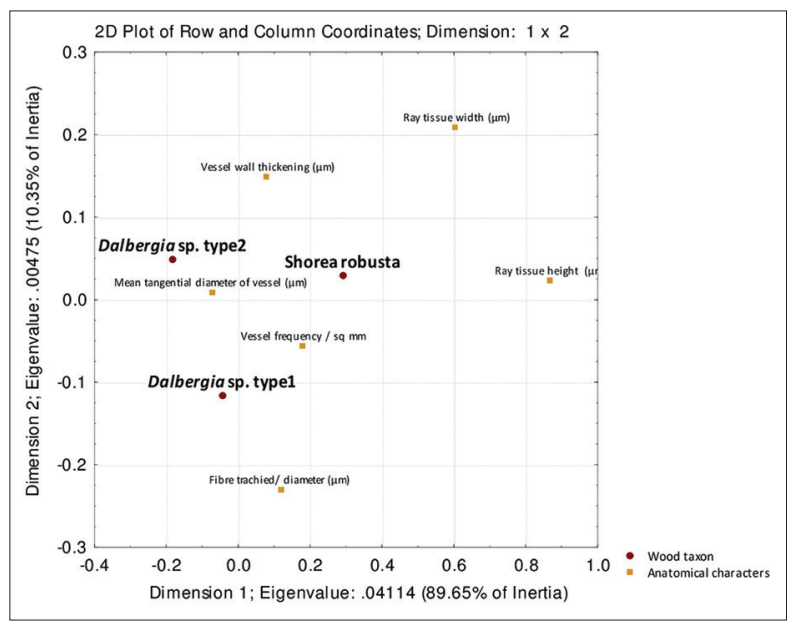

Figure 6: Biplot showing the results of correspondence analysis of collected Sal woods and their xylotomical characters

correspondence biplot due to the significant difference in their secondary xylem characters (Figure 6).

Hierarchical cluster analysis of collected Sal wood samples was also performed applying the Ward's method. The Euclidean distance in the hierarchical cluster shows that $S$.

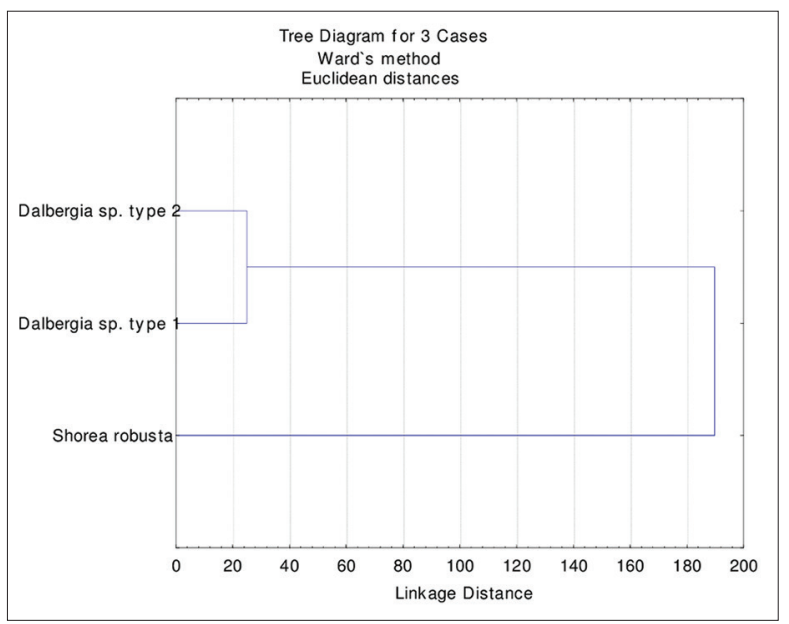

Figure 7: Tree diagram of hierarchical cluster analysis of Sal woods

robusta is significantly different from the Dalbergia sp. Types I and II, but some ancestral linkage were found between the Dalbergia sp. Type-I and Dalbergia sp. Type-II. It clearly indicates that both samples are species of the same genus, i.e. Dalbergia (Figure 7).

\section{CONCLUSIONS}

This study clearly demonstrates that xylotomical study of commercially used woods can play a significant role for the provenance of their authenticity. Secondary xylem structures of plants are very efficient to identify a plant up to its family, generic or specific level. It was found that furniture, carvings and other commercially sold wooden products made by Sandal, Red sander, and Sal woods were faked by the local manufacturers in Kolkata. Thus, this study indicates that sometimes it is also possible to trace an illegal transport of wood having high medicinal properties or importance as expensive timber and the identification of wood may trap the traders and stop such illegal trading of wood. It is not always possible to identify 
a tree species from this kind of fragmentary examination. However, comparison with known samples may provide an idea of the type of timber involved. Thus, xylotomical features may be utilized as an effective tool to measure the authenticity of a wood of commerce.

\section{REFERENCES}

Clavers F. In: Briggs WM, editor. Practical Botany. London: University Tutorial Press Ltd., Drury Lane, W.C; 1911.

Graham S. Anatomy of the Lindbergh kidnapping. J Forensic Sci 1997;42:368-77.

Illic T. The CSIRO Family of Hardwood Identification. Leiden: E.J. Brill; 1987.

Kerley ER, Ubelaker DH. Revisions in the microscopic method of estimating age at death in human cortical bone. Am J Phys Anthropol 1978;49:545-6.

Metcalfe CR, Chalk L. Anatomy of Dicotyledons 1 and 2. Oxford: Clarendon Press; 1950.
Miller RB. Identification of wood fragments in trace elements. In: Proceedings of International Symposium on the Forensic Aspects of Trace Elements. Virginia: U.S. Department of Justice Federal Bureau of Investigation, FBI Academy, Quantico; 1994. p. 91-111.

Quatrehomme G, Lacoste A, Bailet P, Grévin G, Ollier A. Contribution of microscopic plant anatomy to postmortem bone dating. J Forensic Sci 1997;42:140-3.

Schweingruber FH. Tree Rings: Basics and Applications of Dendrochronology. Dordrecht, Novanet: Reidel D. Publishing Company, Dalhousie Killam Library; 1988.

Vanezis P, Sims BG, Grant JH. Medical and scientific investigations of an exhumation in unhallowed ground. Med Sci Law 1978;18:209-21.

Ward J. Hierarchical grouping to optimize an objective function. J Am Stat Assoc 1963;58:236-44.

Willey P, Heilman A. Estimating time since death using plant roots and stems. J Forensic Sci 1987;32(5):1264-70. 